\title{
Sensory Evaluation and Consumers Acceptability of Some Yam (Dioscorea rotundata) Cultivars Used as Parents in a Yam Varietal Development Program in Benin
}

\author{
Fakorede Jeannette $^{1}$, Sanoussi Faouziath ${ }^{1}$, Loko Yêyinou LauraEstelle ${ }^{2}$, Tchekessi \\ Célestin $^{3}$, Igwe Chima Cartney ${ }^{4}$, Bokossa Yahou Innocent ${ }^{3}$ and Dansi A. Alexandre ${ }^{1^{*}}$
}

${ }^{1}$ Laboratoire de Biotechnologies, Ressources Génétiques et Amélioration des Espèces Animales et Végétales (BIORAVE), Ecole Nationale Superieure des biosciences et biotechnologies appliquées (ENSBBA), BP 143 Dassa-Zoumè, Benin. ${ }^{2}$ Laboratoire d'Entomologie Appliquée (LEnA), Ecole Nationale Supérieure des Biosciences et Biotechnologies Appliquées (ENSBBA), BP 14 Dassa

${ }^{3}$ Unité de Recherche en Sécurité Sanitaire des Aliments (URSSA), Laboratoire de Microbiologie et des Technologies Alimentaires (LAMITA), Département de Biologie Végétale de la Faculté des Sciences et Techniques (FAST), Université d'Abomey-Calavi (UAC), Bénin, 04BP 1107 Cotonou,

${ }^{4}$ Federal Institute for Industrial Research, Oshodi, Lagos state, Nigeria

*Corresponding author

\section{A B S T R A C T}

\begin{tabular}{l}
\hline Ke y w o r d s \\
Acceptability, \\
Hedonic test, \\
Sensory test, \\
Tasters, Yam \\
\hline Article Info \\
\hline $\begin{array}{l}\text { Accepted: } \\
\text { 15 February } 2020 \\
\text { Available Online: } \\
\text { 10 March } 2020\end{array}$ \\
\hline
\end{tabular}

The improvement of yam (Dioscorea spp) nutritional quality is now an important challenge for yam breeders and producers. In order to identify yam parents with high technological potential for their use in varietal improvement schemes, two most dominant cooking forms (boiled and pounded) were considered. A total of 48 yam (Dioscorea rotundata Poir.) cultivars used as parents in Benin yam breeding program were evaluated. Trained and untrained panelists were invited to taste coded and randomized samples of boiled and pounded yam for the various tests using appropriate methods. Attributes considered for the evaluation of the sensory profile were attractiveness, sweetness, texture, elasticity, presence of lumpsand cooking time. The hedonic test was based on five scales ranging from very unpleasant to very pleasant. Principal component Analysis carried out on the preferences of the tasters showed that $29.16 \%$ of the cultivars are preferred in the boiled form, $(27.08 \%)$ in pounded form and $43.75 \%$ in both forms. In the hedonic test, $15 \%$ of the cultivars were rated as very pleasant, $54 \%$ were pleasant, $8.33 \%$ were neither-pleasant nor-unpleasant (neutral), $14.58 \%$ unpleasant and 7.25 very unpleasant. The mean score of texture, softness, elasticity and color, vary respectively from 1 to 3.16 ; 0.75 to 3.25 ; 0.98 to 3.75 ; and 0.66 to 1.34 . The principal component analysis revealed six organoleptic groups of interest. Sweetness, texture, and attractiveness were found to determine the general preference for boiled yams while for the pounded yam preference was based on elasticity, softness and texture. Best parents identified for both boiled and pounded yam were Boniakpa, Djilaja, DrA39-2003, Kpagninan, Kpounan, Krachi, Laboko, Tarayè and Wouroutani. Their use in the development of new varieties to respond to consumers and processors needs was highly recommended. 


\section{Introduction}

Yam (Dioscorea spp), widely grown in West Africa, is an important source of calories and feeds for several millions of people (FAO, 2018).Among the existing cultivated yam species in the subregion, the most produced and consumed is Dioscorearotundata Poiralso referred as guinea yam (Loko et al., 2013). Through its nutritional importance, it ensures food security of households (Otegbayo et al., 2006). In Benin, the annual yam production was 2944944 tons in 2018 (FAOSTAT2018). The country is among the largest consumers of yams with an annual consumption of $161.41 \mathrm{~kg}$ per person (FAO, 2018). Consumption forms are mostly boiled yam, pounded yam, fried yam and Amala with the two first being the most popular (Ojokoh and Adeleke, 2019). Due to its intraspecies genetic diversity, edible yam tubers offer varying processing abilities as they differ in term of food quality. The food quality of tubers used to produce yam dishes is a major criterion for the acceptability of new yam cultivars by producers, processors and consumers (Nindjin et al., 2006). Processors for instance have preference for yam cultivars with good textural qualities that can give elastic and smooth pounded yam (Akissoe et al., 2006). A perceived poor textural quality can have a negative impact on the acceptability of the products by the consumers.

In variety development, sensory evaluation is not only the most important hurdle after all the necessary agronomic characteristics have been developed but also a major determinant of acceptability of the variety, as well as a major determinant in the subsequent adoption and use of the variety. According to Kohyama (2020), sensory quality is a group of physical characteristics that derives from the perceived structure of the food by sense organs. The main factors of consumers' acceptability are texture, flavor, tenderness, elasticity and attractiveness. Texture is an important indicator of the quality of pounded yam, and the most relevant sensory qualities for the product are elasticity and flavor. Yam producers rely on their sensory evaluation to confirm the main positive attributes of the good quality of pounded and boiled yams and to evaluate new varieties (Akissoé et al., 2003). For Akissoé et al., (2003) the inefficiency of sensory evaluation techniques to identify successful cultivars, is a handicap for the improvement of the quality of the products. The evaluation tools will enable to identify by means of effective methods, the tubers of good textural qualities and then, allow the breeders to choose the most efficient yam cultivars with good attributes and culinary qualities. The present study aims to evaluate the technological aptitude and acceptability for the production of boiled and pounded yams of each of the 48 yam cultivars used as parents in the yam breeding program in Benin

\section{Materials and Methods}

\section{Materials used and preparation of samples}

Fresh tubers of 48 yam (D. rotundata) cultivars involved in yam breeding program in Benin were considered (Table 1). These cultivars were routinely maintained at the experimental farm of the Laboratory of Biotechnology, Genetic Resources and Animal and Plant Breeding (BIORAVE)based at Hlagba Lonmè in the district of Zogbodomey in southern Benin.

The samples subjected to the various sensory tests were produced and prepared under the same conditions and with the same method following Ojokoh and Adeleke (2019). Yam samples were coded with a three-digit random number. Matured (8 months) yam tubers were carefully selected and washed by hand in 
potable water before peeling with sharp stainless steel blades knives. The peeled yams were secondly washed in potable water before slicing using a kitchen slicer with adjustable stainless steel blades. A mass of $2 \mathrm{~kg}$ of sample were brought to cooking with a quantity of about $200 \mathrm{ml}$ of water and at a temperature of $100^{\circ} \mathrm{C}$. The duration of normal cooking varied with cultivars and was measured for each cultivar. Yam pounding machine trademarked GASA was used to pound the sampled tubers.

Sensory evaluation and assessment of consumer acceptability of the different cultivars

The combination of codes have been produced by type of test. They were put in identical porcelain dishes and placed on the bench by combination. Four (04) samples of boiled and / or pounded yams were selected randomly among cooked/ pounded samples and submitted to the consumer assessment per day for each of the tests. Three sensory tests were performed. Each panelist was given a combination of samples, a scorecard and a glass of water to rinse the mouth between two samples. The panelist were invited to appreciate the samples on the evaluation sheet. The cards duly completed by these panelists were removed at the end of the evaluation and the data were organized and processed. A minimal training was made for the chosen panelist to establish the sensory profile: principle of notation or appreciation, filling of the scoring sheet, nature of the sample, the parameters to be evaluated. The tasting sheets was designed according to the sensory tests to be performed.

For the hedonic test, the panel consists of 60 tasters chosen at random and trained for the occasion. Coded yam samples were presented to each panelist in a randomized order. The sensation perceived by each panelist is marked on a 5-level hedonic scale ranging from very unpleasant to very pleasant (KiinKabari et al., 2015).

For the preference test, the panel also consists of 60 untrained tasters, recruited on the basis of their availability. Boiled and pounded yams under the same conditions are presented simultaneously to each panelist following a blind distribution (coded samples). For quantitative descriptive analysis or sensory profiling, the method consisted of evaluating and quantifying the appropriate descriptors (aroma, taste, hardness or chewing consistency, attractiveness, elasticity and presence or absence of lumps) according to a category scale. The general assessment criteria for boiled yams are based on texture, taste, aroma and attraction, whereas for pounded yams they are based on elasticity, texture, attraction and taste. Boiled and pounded yams made from different cultivars are presented to a panel of 12 judges recruited and initiated to the methodology of analysis.

\section{Statistical analysis}

The results obtained from the various tests carried out were submitted to descriptive statistics, to multi-variate analysis (Principal Component Analysis) and Correspondence Factor Analysis (CFA) and finally to the $\mathrm{R}$ software significance model. $\mathrm{R}$ software and the Minitab 17 were used to process the data obtained. The minitab 17 software was used to perform the descriptive statistics of the data obtained and the software $(\mathrm{R})$ to perform the statistical model, principal component analysis (PCA) and Factorial Correspondence Analysis (CFA) to link varieties to variables.

\section{Results and Discussion}

\section{Evaluation of consumer preference}

The analysis of the results of the preference test reveals 3 categories of preference for the yams cultivars evaluated. These are: the 
preference for the boiled type alone (BS), the pounded type alone (PS) and finally the cultivars for both types of processing (boiled and pounded-BP). Figures 1 and 2 presented the factorial analysis of the correspondences grouping the cultivars according to the preference of the tasters and the frequency of preference by category.

The factorial analysis of the correspondences computed to determine the preferred types for each cultivar by the panelist shows that axes 1 and 2 account for $100 \%$ of the variability of preferences according to the tasters. Axis 1 $(67.13 \%)$ and axis $2(32.87 \%)$ alone account for $100 \%$ of the variability among the cultivars analyzed.

The projection of the two axes in the factorial plane shows that the cultivars, Idoro (237), Dambani (226), Singor (242), Yonouan (216), Effourou (220), Gaboubaba (234), Wokiri (218), Alsoura (222), Zamber (248) are only preferred in the boiled form alone with cultivars such as Effourou (220), Idoro (237), most preferred by $75 \%$ and $66.66 \%$ of the tasters respectively (Figure 1).However, Krachi (240), Tarayè (245), Bakarou (224), Debate (227), Kpagninan (118), Ahimon (221), Parayobou (115), DrA52003 (231), anklouman (116) are only preferred in the pounded form and the cultivars khrachi (240), Tarayè (245) were most appreciated cultivars by $90 \%$ and $80 \%$ of the tasters, respectively. According to the panelists, there are also some yam cultivars that maybe as well appreciated in both forms of processing. They are Djiladja (228), Morokorou (210), Gominan (236), Laboko (112), Kpounan (211) Amoula (223), Wouroutani (213), Baniouré (225), Kagourou (238), Wété (212), Dra39-2003 (230), Angbaobe (119), Dodo (243), DrA21-2003 (229), Tchéé (244) etc. Here the cultivars Labôkô (112), Kpounan (211), Wourtani (213), Môrôkorou (210) recorded the highest overall acceptability proportions of (80-95\%) expressed by the tasters (Figure 1).

Figure 2 showed that $29.16 \%$ of the cultivars are preferred in the boiled form alone (BS), $(27.08 \%)$ in pounded form alone (PS) and $43.75 \%$ of the cultivars were preferred in both forms boiled and pounded (BP).

\section{Hedonic tests}

The pleasant or unpleasant taste of the cultivars was measured on a five-point hedonic scale. The results were shown in Figures (3, 4 and 5).

Consumers acceptability study results from these cultivars of D.rotundata (Figure 3) showed that more than half of the cultivars $(52.08 \%)$ were rated pleasant, $14.58 \%$ very pleasant and $14.58 \%$ of unpleasant, then respectively $8.33 \%$ and $7.25 \%$ are qualified neutral (neither pleasant - nor unpleasant) and very unpleasant by the tasters. The significance model constructed on the basis of software R (Figure 4) has shown that the differences of appreciation between the scales proposed are insignificant at probability $\mathrm{P}>$ 0.05 .

The results of the statistical model carried out show the absence of significant differences in taste between the level of acceptability of cultivars by panelist. Indeed, the variance observed for all these levels reveals a ratio $\mathrm{F}$ $=1.084$ between the different scales, this value is lower than the theoretical value (4) given by the statistical table. Cultivars that were found to be very pleasant and those rated pleasant correspond to score 5 and 4 (Figure 3 ) of the rating scale. Thus, cultivars Laboko (112), DrA39-2003 (230), Kpagninan (118), Djilaaja (228) and Kpounan (211) were considered very pleasant. There are also cultivars that have been judged to be neutral (neither-pleasant-nor-unpleasant), that is to 
say which does not have any taste for the judges (Figure 3). These were cultivars Gnidou (235), Babetéi (111), dodo (243) which correspond to level 3 of the appreciation scale. Only three samples Assina (219), Dambani 226), Yonouan (216) are described as very unpleasant (level 1 of the scale) by the panelists (Figure 6b). In sum, of the 48 cultivars of D.rotundata yams evaluated, $32(66,66 \%)$ cultivars (Figure5) are were well appreciated by the tasters and presented very good taste characteristics. Evaluation of the sensory profile Tables 2 and 3present the means of the sensory profile scores of each of the $D$. rotundata varieties used as a parent in the breeding program in Benin and the descriptive statistics of the means of the scores of the parameters studied.

The evaluation of the organoleptic quality of each of the pounded and boiled yam samples was performed according to a descriptive analysis of the sensory profile. This test allowed to evaluate the appropriate attributes like: the attraction of the color, the time of cooking, the sweetness, the aroma, the texture, the elasticity, the presence or not of lumps. The results of the analyzes indicated that the differences between of yams cultivars tested are highly significant in terms of the 07 descriptors utilized ( $p>0.5$ ). For the evaluation of the repeatability between the same descriptor, the descriptive statistics were performed. Hence it appears that for the taste descriptor (sweetness), a significant variation was observed with a coefficient of variability equal to 35.3 between the average of the scores of the tasters.

The sample (230) DrA39-2003, Labôkô and Kpagninan are the most appreciated for the attribute sweetness by the panelists with the maximal score average equal to 4 while (E19) Assina represents the least appreciated for this same attribute with an average of the minimum scores $(\mathrm{msm}=0.75)$. These last groups of cultivars are described as bitter or sometimes tasteless.

The evaluation of the texture (hardness) showed that there is also a significant variability between the studied samples, with a coefficient of variation equal to 35.98 between the average of the computed scores. However, the Samples (217) Boniakpa, (219), Assina, (221) Ahimon, and (247) Yaassi expressed the highest scores for this attribute, so qualified as very hard with the average of the Maximum scores which is around equal to 4.16 while the samples (235) Gnidou, (248) Zember had the lowest scores, about 1, so can be qualified as non-hard cultivars (with high water content).

Similarly, the analysis of the results of the elasticity test performed on these 48 cultivars reveals that the stretching behavior varies from one variety to another with a coefficient of variability equal to 31.57 . Indeed cultivars Krachi, Taraï, Laboko, Kpounan expressed the higher scores for the panelists in regard to the level of elasticity with an average a maximum score equal to (3.75) expressed by Krachi.

Moreover, the analysis of the aroma descriptor showed a great variability with a coefficient of variability equal to 200. The cultivars Labôkô Kpagninan and Tarai recorded the highest score. These cultivars are also highly attractive compared to Bobotchinga, Wokiri, which has no attraction.

Then, the descriptor presence of lumps is also an undesirability factor for the tasters and expresses a very great variability equal to 223and presents the highest score in some cultivars like Taraï, Assina. It has also been found that cultivars having the hard texture have a relatively long cooking time. So there is a relationship between the cooking time and the texture presented by the cultivars studied. 
Figure 6 shows the variation of the cooking time (in minutes) as a function of the texture. The disintegration induced by heat varies from one variety to another.

Figure $7 \mathrm{a}$ and $7 \mathrm{~b}$ show the correlation between the tested attributes as well as the structure of the cultivars according to their organoleptic characteristics The matrix of the data constituted in line by the cultivars and in column by the variables shows that the axes 1 and 2 explain $55.05 \%$ of the variability, which is satisfactory to guarantee a good interpretation. On axis 1 the variables cooking time (min), texture (txtur), lumps have a positive correlation greater than 0.5 so significant. On the other hand, the soft (soft), attractive (Attray) variables are significantly and negatively correlated on the same axis. On axis 2, the variable elasticity, attractiveness and softness have a positive correlation and greater than 0.5 , so significant whereas the aroma variable is correlated neither on the axis1, nor on the axis2 so it presents itself as a variable not significant with a correlation less than 0.5 . It can be concluded that the axis 1 is characterized by cultivars of poor textural quality but good taste qualities and the axis2 is characterized by varieties of very good taste and textural quality.
The projection of the axes on the factorial plan allows to group the cultivars in 5 groups of sensory interest. At the end of the interpretation of the different graphs, we note that group $(\mathrm{G})$ :

G1: consists of three cultivars or $6.25 \%$ of cultivars studied, it is (245) Taraï, (240) Krachi, which are qualified cultivars of very hard texture and very elastic, of attractive appearance, and sweet flavor while;

G2: consists of five cultivars or $10.41 \%$ of cultivars to study, it is (112) Laboko, (244) Tché, (211) kpouna, (230) DrA39-2003, (246) wokourou who after the analysis seem to qualify cultivars of very good taste quality, presenting sweet taste, elastic texture, and soft and sometimes slightly hard then very attractive.

G3: Is composed of 21 or $43.75 \%$ studied cultivars such as 213 (Wouroutani), (119) Angbaobé, 243Dodo, (226) Baniouré (233) Effourou (223) Amoula, Djiladja, (210) Môrôkorou, (229) DrA21-2003, (231) DrA52003, (232) DrA65-2003 etc. as for them, characterized by a slight elasticity of sweet taste, attractive and of soft texture thus very friable.

Table.1 List, code, sex and nature of different $D$. rotundata cultivars analysed

\begin{tabular}{|l|l|l|l|}
\hline Vernacular name & Code & Sex & Cultivar type \\
\hline Adani & 220 & Male & Landrace \\
\hline Agbaobé & 119 & Male & Landrace \\
\hline Ahimon & 221 & Femelle & Landrace \\
\hline Alssoura & 222 & Male & Landrace \\
\hline Amoula & 223 & Male & Landrace \\
\hline Anklouman & 116 & Femelle & Landrace \\
\hline Assina & 219 & Male & Landrace \\
\hline Babétéi & 111 & Male & Landrace \\
\hline Bakarou & 224 & Male & Landrace \\
\hline Baniouré & 225 & Femelle & Landrace \\
\hline
\end{tabular}




\begin{tabular}{|l|l|l|l|}
\hline Bobotchinga & 113 & Male & Landrace \\
\hline Boniakpa & 217 & Male & Landrace \\
\hline Dambani & 226 & Male & Landrace \\
\hline Déba & 227 & Male & Landrace \\
\hline Djiladja & 228 & Male & Landrace \\
\hline Dodo & 243 & Male & Landrace \\
\hline DrA $\mathbf{2 1}_{\mathbf{2}} \mathbf{2 0 0 3}$ & 229 & Femelle & Hybride \\
\hline DrA $\mathbf{3 9}_{\mathbf{2}} \mathbf{2 0 0 3}$ & 230 & Femelle & Hybride \\
\hline DrAs-2003 & 231 & Femelle & Hybride \\
\hline DrA65-2003 & 232 & Femelle & Hybride \\
\hline Effourou & 233 & Femelle & Landrace \\
\hline Gaboubaba & 234 & Femelle & Landrace \\
\hline Gnidou & 235 & Femelle & Landrace \\
\hline Gominan & 236 & Male & Landrace \\
\hline Hêapala & 114 & Femelle & Landrace \\
\hline Idoro & 237 & Male & Landrace \\
\hline Kagourou & 238 & Male & Landrace \\
\hline Katala & 239 & Femelle & Landrace \\
\hline Kpagninan & 118 & Male & Landrace \\
\hline Kpakara & 214 & Male & Landrace \\
\hline Kpouna & 211 & Male & Landrace \\
\hline Kratchi & 240 & Femelle & Landrace \\
\hline Labôkô & 112 & Male & Landrace \\
\hline Môrôkorou & 210 & Femelle & Landrace \\
\hline Parayobou & 215 & Femelle & Landrace \\
\hline Portchabim & 241 & Male & Landrace \\
\hline Singor & 242 & Male & Landrace \\
\hline Soussouka & 115 & Male & Landrace \\
\hline Tarayè & 245 & Femelle & Landrace \\
\hline Tchéé & 244 & Femelle & Landrace \\
\hline Wété & 212 & Femelle & Landrace \\
\hline Wokiri & 218 & Male & Landrace \\
\hline Wokourou & 246 & Femelle & Landrace \\
\hline Wouroutani & 213 & Male & Landrace \\
\hline Yakanougo & 117 & Male & Landrace \\
\hline Yassi & 247 & Male & Landrace \\
\hline Yonouan & 216 & Femelle & Landrace \\
\hline Zambè & 248 & Male & Landrace \\
\hline & & & \\
\hline
\end{tabular}


Table.2 Cooking Time and Sensory characteristics of yams cultivars analysed

\begin{tabular}{|l|l|l|l|l|l|l|l|l|}
\hline $\mathbf{C E}$ & $\begin{array}{l}\text { Local } \\
\text { names }\end{array}$ & Times & Sweetness & Aroma & Hardness & Lumps & Elasticity & Colors \\
\hline $\mathbf{2 2 0}$ & Adani & 37 & 1.02 & 0.08 & 3.33 & 1 & 2.91 & 1 \\
\hline $\mathbf{1 1 9}$ & Agbaobé & 17 & 1.83 & 1 & 2.16 & 0 & 2.66 & 1.5 \\
\hline $\mathbf{2 2 1}$ & Ahimon & 35 & 2.35 & 0 & 4 & 0 & 2 & 0.83 \\
\hline $\mathbf{2 2 2}$ & Alssoura & 27 & 2.83 & 0 & 2 & 0 & 1.91 & 1.25 \\
\hline $\mathbf{2 2 3}$ & Amoula & 20 & 2.25 & 0 & 2.16 & 0 & 2.41 & 2 \\
\hline $\mathbf{1 1 6}$ & Anklouman & 21 & 2.25 & 0.16 & 1 & 0 & 1 & 1 \\
\hline $\mathbf{2 1 9}$ & Assina & 27 & 0.75 & 0.41 & 4.08 & 1 & 2.33 & 1.16 \\
\hline $\mathbf{1 1 1}$ & Babétéi & 19 & 3.66 & 0.08 & 2.58 & 0 & 3.16 & 1 \\
\hline $\mathbf{2 2 4}$ & Bakarou & 22 & 3.25 & 0.08 & 1.66 & 0 & 2.75 & 1 \\
\hline $\mathbf{2 2 5}$ & Baniouré & 24 & 3 & 0 & 2 & 0 & 2.08 & 0.94 \\
\hline $\mathbf{1 1 3}$ & Bobotchinga & 24 & 1.02 & 0.16 & 2.75 & 0.08 & 3.41 & 1 \\
\hline $\mathbf{2 1 7}$ & Boniakpa & 35 & 1.33 & 0.08 & 4.16 & 0.83 & 3.42 & 1 \\
\hline $\mathbf{2 2 6}$ & Dambani & 25 & 3 & 0 & 2 & 0.08 & 2 & 1.66 \\
\hline $\mathbf{2 2 7}$ & Déba & 18 & 2.85 & 0 & 2.25 & 0 & 3 & 1 \\
\hline $\mathbf{2 2 8}$ & Djilaadja & 18 & 3 & 2 & 1.5 & 0 & 1 & 1 \\
\hline $\mathbf{2 4 3}$ & Dodo & 27 & 3 & 0 & 1.33 & 0 & 2.75 & 1.5 \\
\hline $\mathbf{2 2 9}$ & DrA21-2003 & 31 & 3.33 & 0 & 1.33 & 0 & 2.5 & 0.91 \\
\hline $\mathbf{2 3 0}$ & DrA39-2003 & 22 & 3.33 & 0.08 & 1.58 & 0 & 3.33 & 1.66 \\
\hline $\mathbf{2 3 1}$ & DrA5-2003 & 30 & 2.91 & 0.91 & 2 & 0 & 2.33 & 1 \\
\hline $\mathbf{2 3 2}$ & DrA65-2003 & 25 & 3 & 0.58 & 2.25 & 0 & 2.33 & 1 \\
\hline $\mathbf{2 3 3}$ & Effourou & 17 & 2.75 & 0 & 2.91 & 0 & 2.25 & 2 \\
\hline $\mathbf{2 4 3}$ & Gaboubaba & 14 & 1.08 & 0 & 2.33 & 0 & 2.83 & 1 \\
\hline $\mathbf{2 3 5}$ & Gnidou & 15 & 1.5 & 0 & 1.31 & 0 & 0.98 & 0.91 \\
\hline $\mathbf{2 3 6}$ & Gominan & 16 & 2.98 & 0 & 2 & 0 & 1 & 1.83 \\
\hline $\mathbf{1 1 4}$ & Hêapala & 26 & 2.08 & 0.16 & 2.75 & 0 & 2.41 & 1 \\
\hline $\mathbf{2 3 7}$ & Idoro & 15 & 2.5 & 0 & 1.5 & 0 & 1.16 & 1 \\
\hline $\mathbf{2 3 8}$ & Kagourou & 23 & 2.91 & 0 & 3 & 0 & 1.41 & 0.92 \\
\hline $\mathbf{2 3 9}$ & Katala & 22 & 1.25 & 0 & 2.25 & 0.41 & 1.83 & 1 \\
\hline $\mathbf{1 1 8}$ & Kpagninan & 18 & 4 & 0 & 3 & 0 & 2.25 & 1 \\
\hline
\end{tabular}




\begin{tabular}{|l|l|l|l|l|l|l|l|l|}
\hline $\mathbf{2 1 4}$ & Kpakara & 32 & 1.83 & 0 & 2.83 & 0.25 & 2.33 & 1.08 \\
\hline $\mathbf{2 1 1}$ & Kpouna & 20 & 3.5 & 0.66 & 1.52 & 0.08 & 3.41 & 1.08 \\
\hline $\mathbf{2 4 0}$ & Kratchi & 34 & 3 & 0 & 3.25 & 0 & 3.75 & 1.66 \\
\hline $\mathbf{1 1 2}$ & Labôkô & 13 & 4 & 1 & 1.5 & 0 & 3.58 & 2 \\
\hline $\mathbf{2 1 0}$ & Môrôkorou & 21 & 3.33 & 0 & 1.83 & 0 & 2.41 & 1 \\
\hline $\mathbf{2 1 5}$ & Paroyobou & 20 & 1.25 & 0.33 & 1.66 & 0 & 2.25 & 1.16 \\
\hline $\mathbf{2 4 1}$ & Portchabim & 25 & 2.08 & 0 & 2.75 & 0.08 & 2.91 & 1 \\
\hline $\mathbf{2 4 2}$ & Singor & 21 & 2.08 & 0 & 2.67 & 0 & 1.33 & 0.66 \\
\hline $\mathbf{1 1 5}$ & Soussouka & 23 & 2.41 & 0 & 2.83 & 0.08 & 2.41 & 1 \\
\hline $\mathbf{2 4 5}$ & Tarayè & 28 & 3.66 & 0.75 & 3.75 & 1 & 3.91 & 0.92 \\
\hline $\mathbf{2 4 4}$ & Tchée & 17 & 3.08 & 0.08 & 1.91 & 0 & 2.91 & 2 \\
\hline $\mathbf{2 1 2}$ & Wété & 19 & 3.08 & 0 & 1.91 & 0 & 2.25 & 1 \\
\hline $\mathbf{2 1 8}$ & Wokiri & 21 & 3.25 & 0 & 2.25 & 0.66 & 1.83 & 0.92 \\
\hline $\mathbf{2 4 6}$ & Wokourou & 22 & 3.33 & 0 & 2 & 0 & 2.67 & 1.91 \\
\hline $\mathbf{2 1 3}$ & Wouroutani & 19 & 3.25 & 0.83 & 1.75 & 0 & 2.16 & 1.25 \\
\hline $\mathbf{2 4 7}$ & Yassi & 27 & 0.91 & 0 & 4 & 0.08 & 2 & 0.92 \\
\hline $\mathbf{1 1 7}$ & Yakounougo & 26 & 2.08 & 0.16 & 2.75 & 1 & 2.41 & 1 \\
\hline $\mathbf{2 1 6}$ & Yonouan & 28 & 2.08 & 0 & 1 & 0 & 0.98 & 1.33 \\
\hline $\mathbf{2 4 8}$ & Zambè & 12 & 3.66 & 0.25 & 1.16 & 0 & 1 & 2 \\
\hline
\end{tabular}

Table.3 Descriptive statistics of the averages of the parameters scores

\begin{tabular}{|c|c|c|c|c|c|c|}
\hline Variable & mean & SE.Mean & St dev & Coefvar & Max & Min \\
\hline Times & 22.87 & 0,86 & 6.01 & 26.30 & 37 & 12 \\
\hline Sweetness & 2.53 & 0.12 & 0.89 & 35.34 & 4 & 0.75 \\
\hline Aroma & 0.18 & 0.05 & 0.37 & 200.75 & 2 & 0 \\
\hline Hardness & 2.30 & 0.12 & 0.82 & 35.98 & 4.16 & 1 \\
\hline Glue & 0.13 & 0.04 & 0.30 & 223.14 & 1 & 0 \\
\hline Elasticity & 2.20 & 0.10 & 0.72 & 31.57 & 3.75 & 0.98 \\
\hline Color & 1.20 & 0.05 & 0.37 & 31.37 & 2 & 0.66 \\
\hline
\end{tabular}


Table.4 Hedonic characteristics of the different cultivars analysed

\begin{tabular}{|c|c|c|c|c|c|c|}
\hline Codes & $\begin{array}{l}\text { Variety } \\
\text { name }\end{array}$ & $\begin{array}{l}\text { Very } \\
\text { pleasant }\end{array}$ & unpleasant & $\begin{array}{l}\text { No pleasant } \\
\text { Nor } \\
\text { unpleasant }\end{array}$ & unpleasant & $\begin{array}{l}\text { Very } \\
\text { unpleasant }\end{array}$ \\
\hline 220 & Adani & 0 & 0 & 10.41 & 58.33 & 28.33 \\
\hline 119 & Agbaobé & 46.66 & 28 & 28.83 & 0 & 0 \\
\hline 221 & Ahimon & 15 & 85 & 0 & 0 & 0 \\
\hline 222 & Alssoura & 13 & 60 & 12.5 & 0 & 0 \\
\hline 223 & Amoula & 21 & 72 & 7.00 & 0 & 0 \\
\hline 116 & Anklouman & 36.66 & 29.83 & 20.41 & 6.25 & 8.00 \\
\hline 219 & Assina & 0 & 0 & 0 & 2.41 & 98.33 \\
\hline 111 & Babétéi & 0 & 12.5 & 73.33 & 10.41 & 0 \\
\hline 224 & Bakarou & 8 & 72 & 0 & 20 & 0 \\
\hline 225 & Baniouré & 8 & 92 & 0 & 0 & 0 \\
\hline 113 & Bobotchinga & 0 & 14.58 & 73.33 & 10.41 & 8.33 \\
\hline 227 & Boniakpa & 30 & 42 & 28 & 0 & 0 \\
\hline 217 & Boniakpa & 0 & 0 & 0 & 65 & 25 \\
\hline 216 & Dambani & 41.66 & 31.25 & 22 & 5 & 0 \\
\hline 226 & Dambani & 0 & 0 & 0 & 10.00 & 90 \\
\hline 228 & Djilaadja & 46.66 & 32 & 10.41 & 6.25 & 4.17 \\
\hline 243 & Dodo & 2 & 20.83 & 50 & 10.41 & 0 \\
\hline 229 & $\operatorname{DrA}_{21}-2003$ & 6 & 92 & 20.83 & 0 & 0 \\
\hline 230 & $\operatorname{DrA}_{39}-2003$ & 50 & 20.833 & 29.17 & 0 & 0 \\
\hline 231 & $\operatorname{DrA}_{5}-2003$ & 39 & 57.00 & 2.08 & 0 & 0 \\
\hline 232 & $\operatorname{DrA}_{65}-2003$ & 7 & 61 & 0 & 0 & 0 \\
\hline 233 & Effourou & 24 & 55 & 14.58 & 4.17 & 2.08 \\
\hline 234 & Gaboubaba & 0 & 0 & 0 & 81.66 & 19.15 \\
\hline 235 & Gnidou & 0 & 10.67 & 88.33 & 10.41 & 0 \\
\hline 236 & Gominan & 3 & 86 & 0 & 0 & 0 \\
\hline 237 & Idoro & 0 & 0 & 0 & 70 & 33.33 \\
\hline 238 & Kagourou & 0 & 97 & 3 & 0.00 & 0 \\
\hline 239 & Katala & 30 & 70 & 0 & 0 & 0 \\
\hline 118 & Kpagninan & 18 & 82 & 0 & 0 & 0 \\
\hline 114 & Kpakara & 11 & 52 & 16.67 & 2.08 & 0 \\
\hline 214 & Kpakara & 15 & 77 & 8 & 0 & 0 \\
\hline 240 & Kratchi & 48.33 & 22.97 & 28.01 & 0 & 0 \\
\hline 112 & Labôkô & 58.33 & 10.41 & 28 & 0 & 0 \\
\hline 210 & Môrôkorou & 10 & 72 & 15.7 & 2 & 0 \\
\hline 115 & Paroyobou & 5 & 95 & 0 & 0 & 0 \\
\hline 241 & Portchabim & 45 & 55 & 0 & 0 & 0 \\
\hline 242 & Singor & 0 & 4.16 & 4.167 & 55 & 36.91 \\
\hline 245 & Tarayè & 11 & 47 & 20.83 & 0 & 0 \\
\hline 244 & Tchée & 38 & 52 & 10 & 0 & 0 \\
\hline 212 & Wété & 12 & 67 & 10.41 & 6.25 & 4.17 \\
\hline 218 & Wokiri & 0 & 0 & 0 & 80 & 10 \\
\hline 246 & Wokourou & 5 & 95 & 0 & 0 & 0 \\
\hline
\end{tabular}




\begin{tabular}{|l|l|l|l|l|l|l|}
\hline $\mathbf{2 1 3}$ & Wouroutani & 14 & 75 & 6.25 & 4.17 & 0 \\
\hline $\mathbf{1 1 7}$ & Yakounougo & 1 & 2.08 & 0 & 65 & 16.66 \\
\hline $\mathbf{2 1 6}$ & Yonouan & 0 & 0 & 0 & 20 & 80 \\
\hline $\mathbf{2 4 8}$ & Zambè & 15 & 47 & 6.25 & 4.167 & 0 \\
\hline
\end{tabular}

Figure.1 Factorial Correspondence Analysis (CFA)

\section{CA factor map}

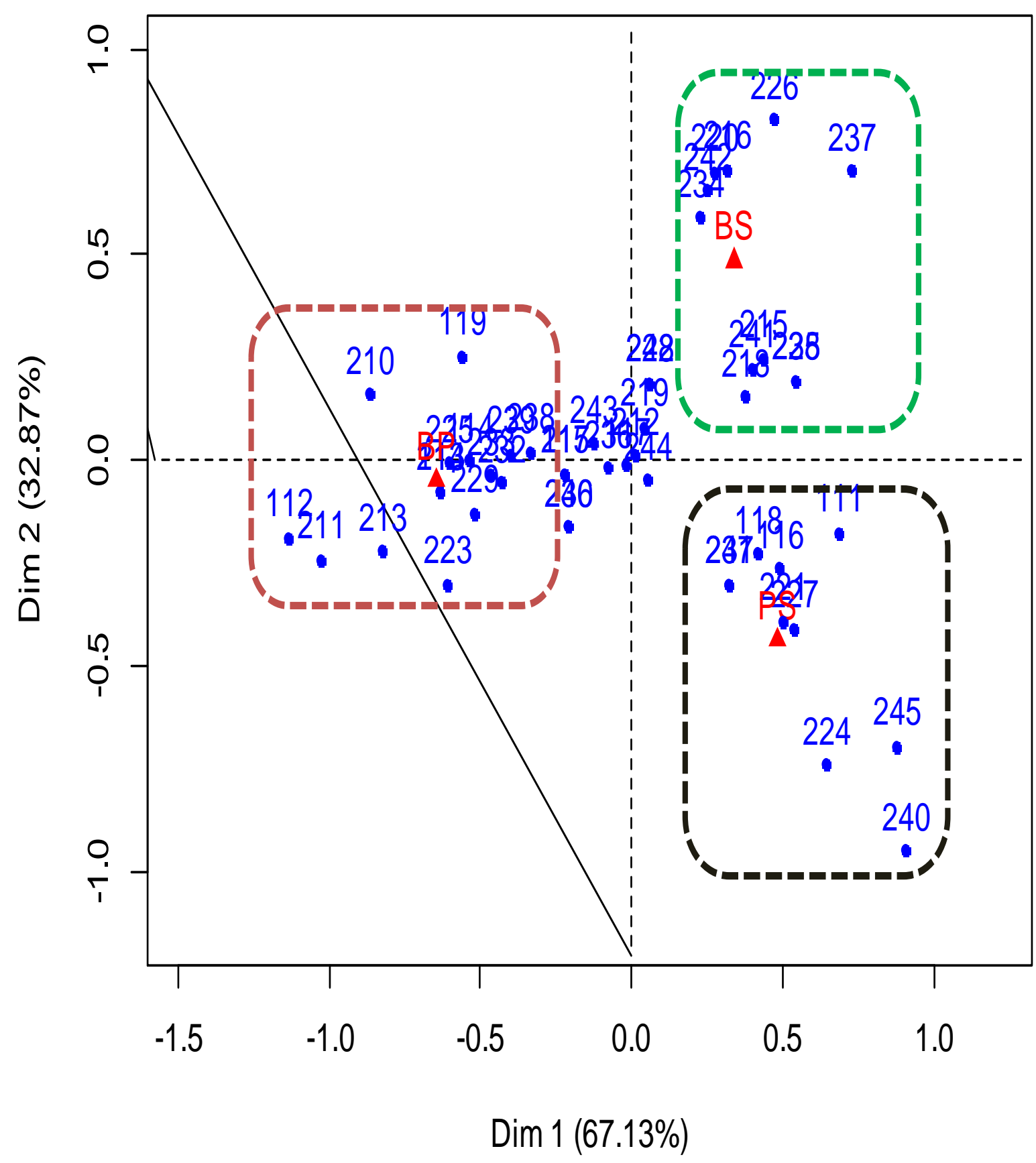


Figure.2 Frequency of preference by category

\section{TYPES OF FREQUENCY}

\section{$27,08 \%$ \\ PS}

\section{$43.75 \%$}

PB

$29.16 \%$

BS

BS PS BP

Figure.3 Frequency of acceptability of yams cultivars by consumers

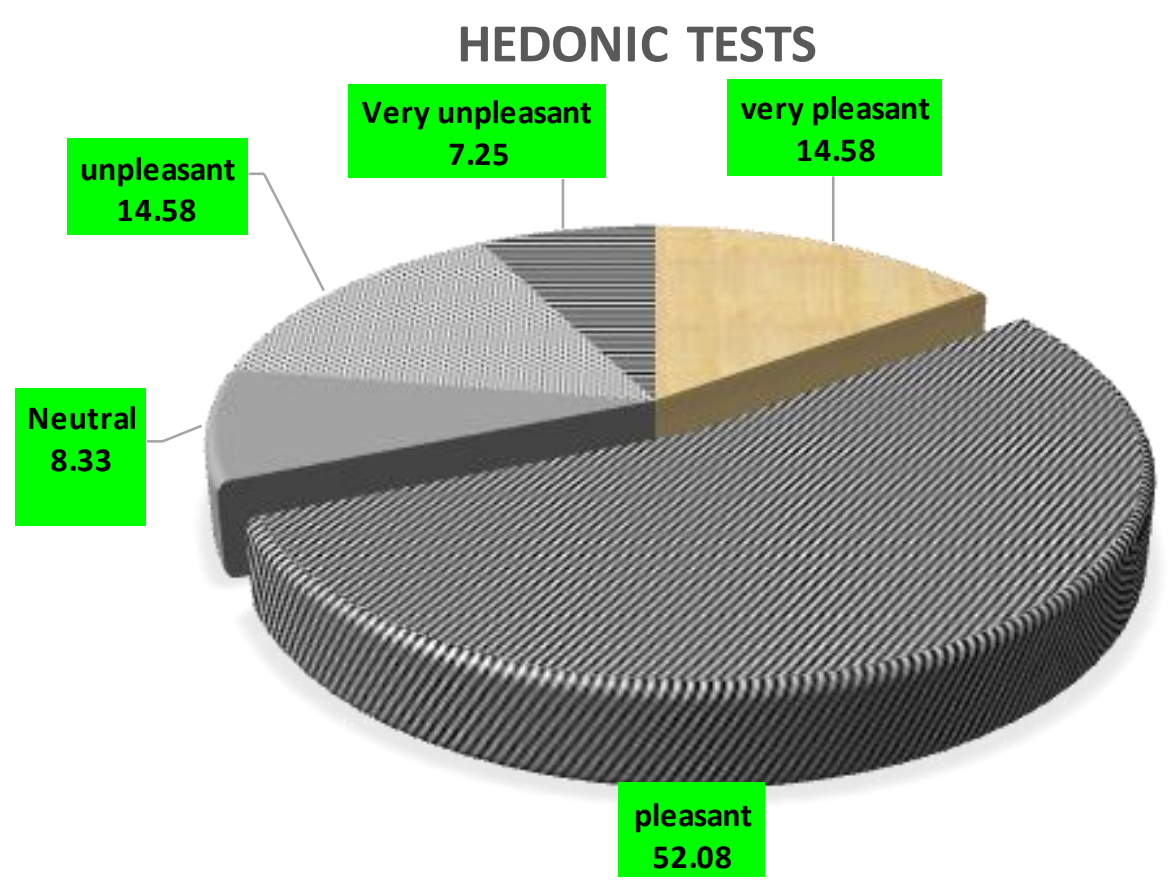


Figure.4 variability of the responses for boiled yam

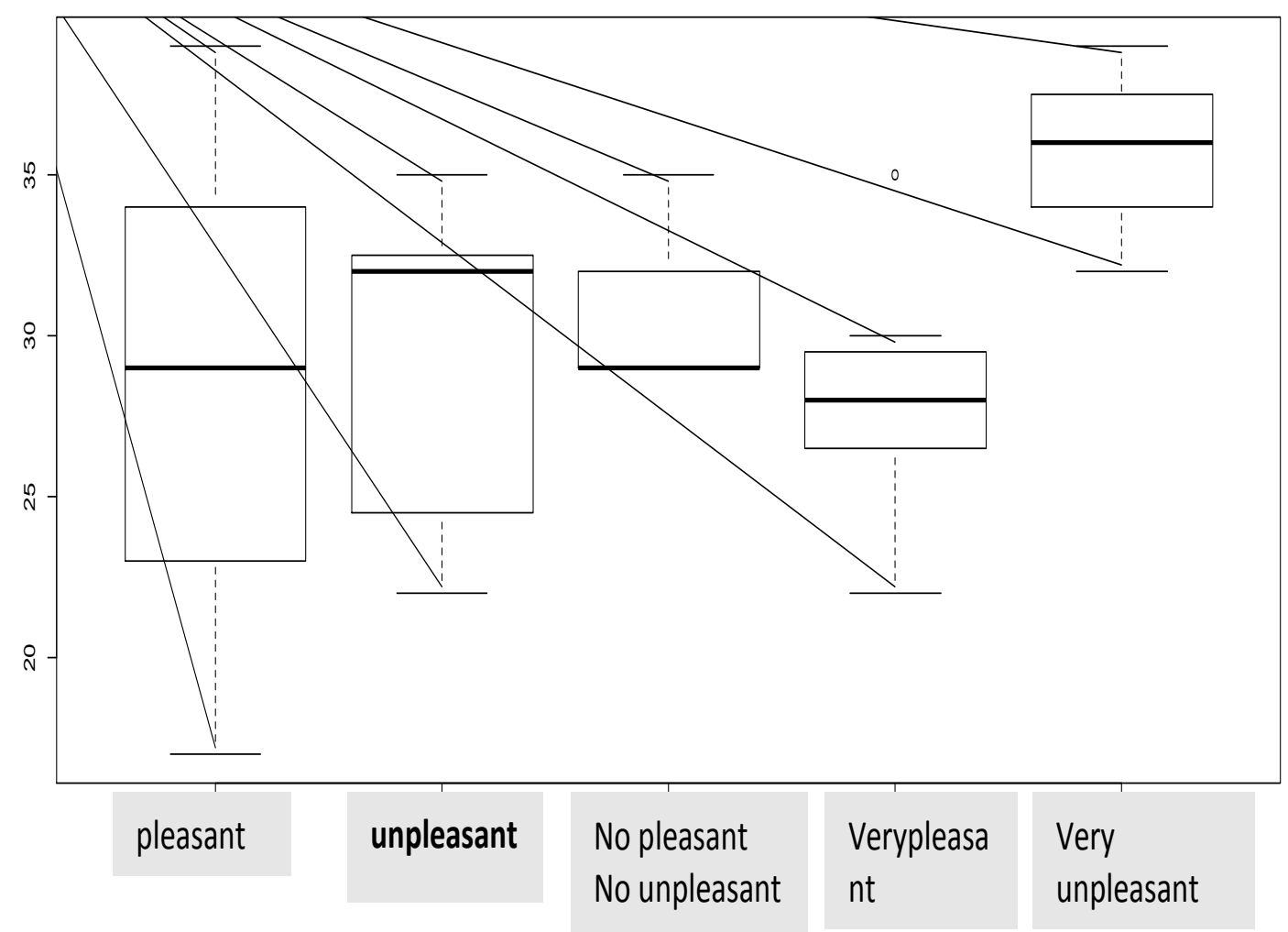

Figure.5 Variation of the cooking time ( $\mathrm{min}$ ) according to the texture

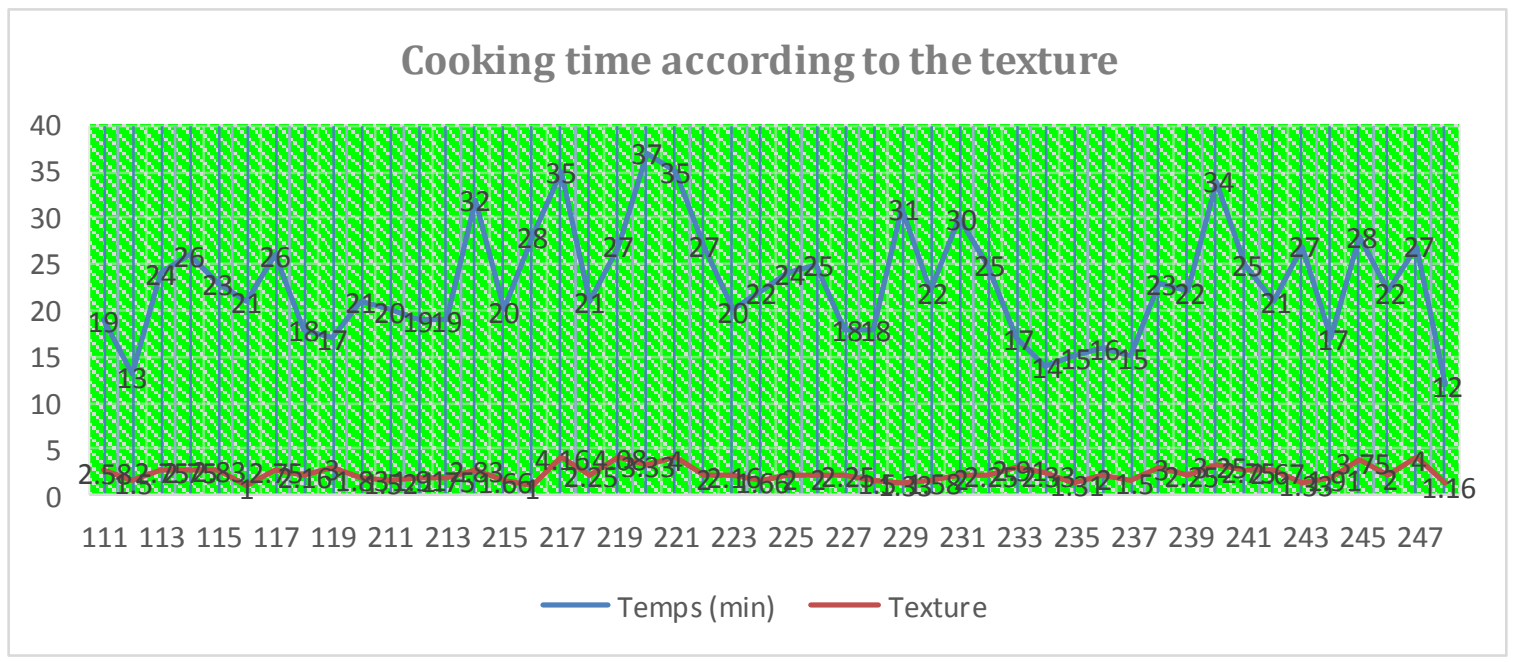


Figures.6 Correlation of the discriminant variables with the two first axis

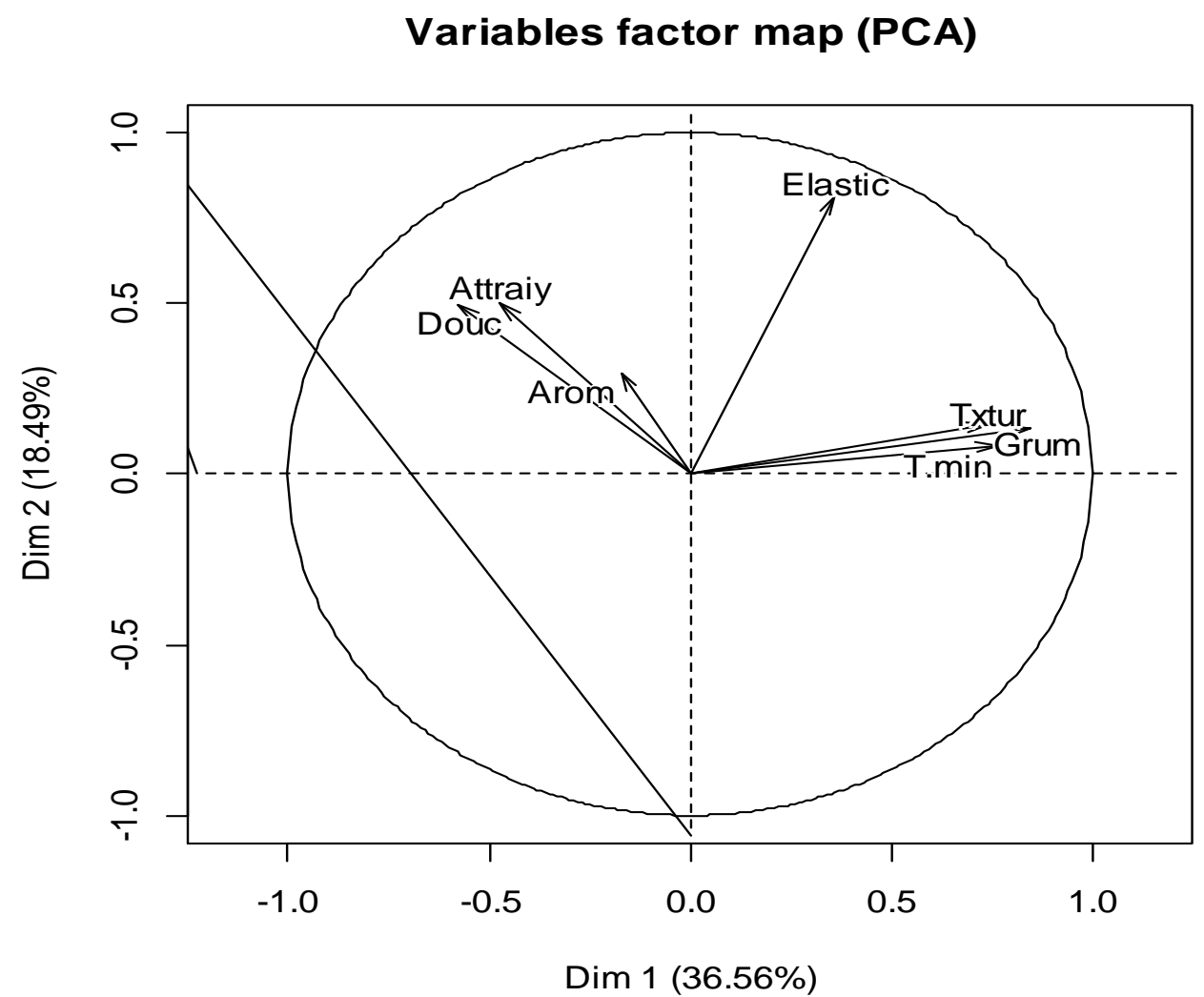

Figure.7 Structuration of the cultivars according to their organoleptic characteristics

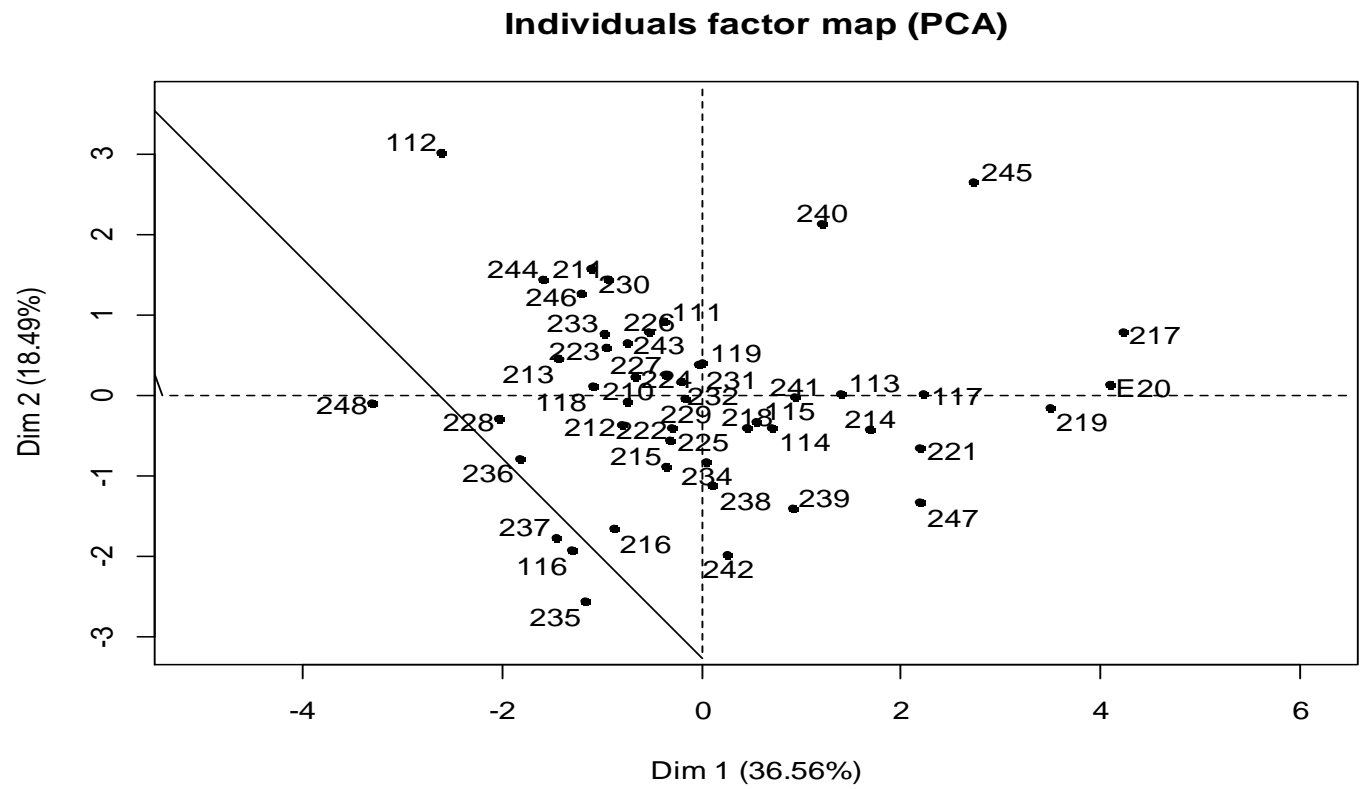


The results obtained, with regard to the sweetness attribute are in agreement with those presented by Bonlanle (2005), (from 1 to 3 ), on some varieties of $D$. rotundata and $D$. alata. The difference in taste between varieties is probably a reason for the difference in sugar content in these varieties (Tortoe et al., 2014). This confirms the results obtained by Fakorede et al., (2017) following the dosage of sugar of these varieties; therefore there is a correlation between the sugar content and the acceptability of the consumer for the taste descriptor. Although sweetness is not the only determinant of yam quality, the sugar level greatly influences its acceptability (Tortoe et al., 2014). Kpagninan and laboko are preferred to other white yams and this preference can be attributed to their sweet taste. Similar comparisons have been substantiated by Ettien et al., (2003) and Adejumo et al., (2013), indicating the preference of pona yam over other white yams and finally attributing this preference to its sweet taste. It has been found that cultivars preferred by tasters are those with high sugar contents (Fakorede et al., 2017). So there is a correlation between taste and consumer preference. Several authors like Tortoe et al., (2013) have also shown that $D$. rotundata is recognized for its excellent taste and is preferred by tasters of $D$. alata and $D$. cayensis. Other authors such as Otegbayo et al., (2006) also reported that the sweetness of characteristic traits is very important and is responsible for the high cost of most tubers on the market.

Regarding the texture studied, the results obtained are similar to those recorded by Ettien et al., (2003) which varies from 5.10 to 0.19. According to this same author, the texture makes characteristic traits for a better acceptability of yam tubers. Oduro et al., (2000) and Ezeocha et al., (2014) reported the constraints related to the difficulties of molding household products with a high texture such as yam. Texture is an important indicator of the quality of pounded yam. However, poor perceived textural quality can have a negative impact on consumer acceptability. Which could justify the reluctance of consumers vis-à-vis of some cultivars like Kpagninan and Krachi that offer sweet taste but elastic texture very hard. Not only have these cultivars had long cooking times, but also their consumption in the boiled form is not always appreciated by consumers. Henceforth, these cultivars seem best indicated because the more water added to the pilling increases, the more the product swells and becomes more profitable. Several authors, such as Dumont and Vernier (1995), have shown that hard cultivars are those which contain less water and are therefore more rich in dry matter and sometimes in starch and are the most suitable in the production of chips for obtaining flours (black dough). The higher elasticity score obtained at cultivars (Krachi) explains an increase in degree of gelatinization with respect to the property of their starches. These types of cultivars seem best suited for the preparation of yam elastic paste (amala and foufou). According to Otegbayo et al., (2006), the swelling properties of starch vary according to their origin and their composition in amylose and amylospectin. The role of soluble amylose on the textural properties of yam paste has also been reported in the literature (Brunnschweiler et al., 2004). For this purpose, the elasticity of these yam pastes could be attributed to the amount of free (or soluble) amylose in the pounded yam. We can then conclude that the adhesive properties of pounded yam paste are mainly influenced by the state of aggregation of amylose. The work carried out by Fakorédé (2017) has shown that the Krachi cultivar contains a significant amount of starch and the major from this starch is composed of amylose and therefore has a very low content of amylospectin and then occurs respectively in the order of 
149.42 and $146.36 \mathrm{mg} / \mathrm{g}$. According to the same author, cultivars with the highest amylose content hydrolyze very slowly than those with the lowest content. And then he thinks that amylose is the part of starch that exists in the form of double chain and is difficult to access by enzymes therefore less sensitive. This could explain the very hard and elastic texture of this cultivar. We can then conclude that the nutritional value of yam tubers can be defined from their organoleptic characteristics, which subsequently define their acceptability. There is therefore a correlation between the nutritional components and the organoleptic characteristics of the tubers to be studied.

Color is a characteristic whose role is to enhance the acceptability of tubers by the appeal it offers to consumers. It is found that during the preparation of boiled yams the flesh of most cultivars is susceptible to browning, which could be the origin of the low score of the recorded color. The observation is also made that the acceptable boiling yam has a white or yellow appearance while the acceptable crushed yam has a high elasticity even if the color is not totally attractive. Tuker et al., (1993) and Baah (2009) attributed this color variation of yam tubers to enzymatic oxidation of these phenolic compounds. Thus some studies have demonstrated that there is a positive correlation between the amount of phenol and the degree of enzymatic oxidation in some varieties of Dioscorea (Asemota et al., 1992, Muzac et al., (1993), Otegbayo (2006).

The correlation obtained on the axis1 (Figure $7 \mathrm{a}$ ) shows that the improvement of the texture in some harder cultivars can lead to a decrease in their duration of cooking and a reduction in the formation of glumaux, but an increase in their levels in sugar. This correlation, although negative, will bring great interest to the selection and will result in not only cultivars of good taste but also textural qualities. The one obtained on axis 2 shows that an increase in the elasticity capacity of some of these cultivars will improve the flavor of these cultivars. On the other hand an improvement of the taste quality (softness) in these cultivars will cause a decrease in the attractive of their colors.

Moreover, the non-correlation of the aroma with any of the axes could be explained by the fact that the aroma is not part of the characteristic attribute of the cultivars studied, and therefore varies very seldom and insignificantly in the cultivars studied. Brunnschweiler (2004) reported that taste, texture and appearance are the primary quality criteria for determining yam selection while odor and color are the secondary quality criteria. These acceptable cultivars had high nutritional compositions such as sugar lipids which function to enhance the level of taste of food. In addition, cultivars such as Gaboubaba and Assina, which are preferred under one or other of the forms, are at the same time disqualified by the same tasters. The criteria for which tasters have not appreciated these cultivars are the bitter taste, the very hard texture, and the lumps they present despite the greater stretching capacity they present

In conclusion, the evaluation of the organoleptic quality of these 48 cultivars of D.rotundata yam reveals the existence of cultivars of great textural and gustative interest. This study of the organoleptic quality of boiled and pounded yam tubers is partly a solution to the problems of adaptation to the technology that actors in the yam sector are facing. Principal component analysis performed on the basis of the sensory profile showed that there is a significant difference between the attributes studied. Cultivars such as Laboko (112), Wouroutani (213), Tarai (245), Krachi (240), Boniakpa (217), DrA39- 
2003 (230), kpagninan (118), Djilaaja (228) and Kpounan (211) have shown satisfactory results. In fact, these cultivars, which are considered to be good at processing, are appreciated as pleasant and very pleasant with an elastic aptitude at stretching, light or hard to the touch and sometimes attractive with a good flavor that varies according to the type of cultivar. Factorial analysis of the correspondences carried out on the preference of the panelists shows that the majority of these cultivars have characteristics of a good pounded and boiled yam. The study of the organoleptic characteristics of these cultivars of D.rotundata in selection in Benin has shown that there are locally cultivars of very good textural qualities that can be involved in the breeding program and food processing chains.

\section{References}

Abiodun O.A.A. and AkinosoA. 2015. Texture and sensory properties of Trifiliate yam (D.dumetorum) flour and stiff dough amala. Journal of food Science and Technology. P: 152

Adejumo BA, Okundare RO, Afolayan OI, and Balogun S A. 2013. Quality Attributes of Yam Flour (Elubo) As Affected By Blanching Water Temperature and Soaking Time. International Journal of Engineering And Science. 2(01): 216-221

Akissoe A., Christian Mestres B., Stephan Handschin C., Olivier Gibert B, Joseph Lebot V, Malapa R, Molisale T, Marchand J., 2006. Physico-chemical characterization of yam (Dioscorea alata L.) tubers from Vanuatu. Gen Res Crop Evolution: 53:1199 -1208.

Akissoe N, Hounhouigan J, Mestres C, Nago M. 2003. How blanching and drying affect the colour and functional characteristics of yam (Dioscorea cayenensis-rotundata) flour. Food
Chemistry, 82: 257-264

Asemota H. N., Wellington M. A., Odutaga A. A. and Ahmad M. A. (1992). Effect of short-term storage on phenolic content, diphenolase and peroxidase activities of cut yam tubers (Dioscoreasp.). J. Sci. Food Agric. 60: 309-312

Baah F.D., Maziyo-Dixon B., Robert A., Oduro, I.N. 2009. Physicochemical and pasting Characterization of water yam (Dioscorea spp) and relationship with eating quality of pounded yam. Journal of food agriculture and environment 7(2); 107.

Bolade KM, Adeyemia I, Ogunsuao A. 2009. Influence of particle size fractions on the physicochemical properties of maize flour and textural characteristics of a maize-based non fermented food gel. International Journal of Food Science and Technology. 44: 646-655

Brunnschweiler I. 2004. Structure and texture of Yam (Dioscorea spp.) and processed yam products. $\mathrm{PhD}$ thesis submitted to the Swiss Federal Institute of Technology. Swiss Federal Institute of technology zurich. Pp. 145

Ettien J B, Tschannen A T, Nindjin C, Asiedu R, Assa A, Girardin O. (2003). Evaluation de nouvelles variétés d'igname en Côte d'Ivoire: bilan de trois ans d'expérience avec des génotypes améliorés par l'IITA. Agronomie Africaine Numéro spécial: 109-116.

Ezeocha V.C. and Ojimelukwe P.C. (2012): The impact of cooking on the proximate composition and anti- nutritional factors of water yam (Dioscorea alata). Journal of Stored Products and Post-Harvest Research. 3(13). 172-176.

FAO (2018). FAOSTAT Database. Food and Agriculture Organization, Roma, Italy. Avaible online at URL: www.fao.org

Kiin-Kabari DB, Ejiofor J, Giami SY. 2015. 
Functional and Pasting Properties of Wheat / Plantain flours Enriched with Bambara Groundnut Protein Concentrate. International Journal of Food Science and Nutrition Engineering. 5(2): 75-81

Kohyama, K. (2020). Food Texture - Sensory Evaluation and Instrumental Measurement. Textural Characteristics of World Foods, 1-13. doi:10.1002/9781119430902.ch

Loko Y L, Dansi A, Agre AP, Akpan, Dossou-Aminon i, Assogba P, Dansi M, akpagana k. et Sanni A. (2013). Perceptions paysannes et impacts des changements climatiques sur laproduction et la diversité variétale de l'igname dans la zone aride du Nnordouest du Bénin. International Journal of Biological and Chemical Sciences. 7(2): 672-695

Muzac-Tucker, I., Asemota, H. N. and Ahmad, M. H. (1993). Biochemical Composition and Storage of Jamaican Yams (Dioscorea sp). Journal of the Science of Food and Agriculture 62:219-224.

Nindjin, C., Otokoré, D., Hauser, S., Tschannen, A., Farah, Z., Girardin, O. (2006). Determination of relevant sensory properties of pounded yams
(Dioscorea spp.) using a locally based descriptive analysis methodology. Food Quality and Preference, 18, 450-459.

Oduro I., EllisW., Aryeetey SK., Ahenkore K. 2000. Pasting characteristics of starch from new varieties of sweet potato. Tropical Science 40(1): 25-28

Ojokoh A., and Adeleke B. (2019). Processing of Yam Paste (Amala): A Product of Fermented Yam (Dioscorea rotundata) Flour. Int. Ann. Sci., 8(1): 87-95.

Otegbayo B., Sakyi-Dawson E., Bokanga M., Robert A. Sensory texture profiling and development of standard rating scales for pounded yam. In Journal of Texture Studies.36: 478-488

Otegbayo, B., Aina, J., Asiedu, R., and Bokanga, M. (2006). Pasting characteristics of fresh yams (Dioscorea spp.) as indicators of textural quality in a major food product.-'pounded yam'. Food Chemistry 99: 663-669.

Tortoe C, Nketia S, Owusu M, Akonor P T, Dowuona $S$ and Otoo E. 2014. Sensory Attributes and consumer Preference of Precooked Vacuum-packaged Yam from Two Varieties of Ghanaian Yam (Dioscorea rotundata) in the Accra Metropolitan Area. Advances in Research. 2(1): 40-51.

\section{How to cite this article:}

Fakorede Jeannette, Sanoussi Faouziath, Loko Yêyinou LauraEstelle, Tchekessi Célestin, Igwe Chima Cartney, Bokossa Yahou Innocent and Dansi A. Alexandre. 2020. Sensory Evaluation and Consumers Acceptability of Some Yam (Dioscorea rotundata) Cultivars Used as Parents in a Yam Varietal Development Program in Benin. Int.J.Curr.Microbiol.App.Sci. 9(03): 20832100. doi: https://doi.org/10.20546/ijcmas.2020.903.239 